\title{
Evaluation of the implementation of sport science programme in Malaysian secondary schools
}

\author{
Eng Hoe Wee ${ }^{\text {a }}$, Ngien Siong Chin ${ }^{2}$ \\ ${ }^{1}$ Tunku Abdul Rahman University College, Jalan Genting Kelang, 53300 Kuala Lumpur, Malaysia \\ ${ }^{2}$ Institute of Teacher Education, Tun Abdul Razak Campus, 94300 Kota Samarahan, Sarawak, \\ Malaysia
}

\begin{abstract}
This study evaluated a new sport science curriculum in Malaysian secondary schools. Four implementation dimensions ('teaching ability', 'administration of sport science programme', 'teaching duty allocation' and 'non-human factors') were examined. 135 schools and 94 teachers were surveyed. $81 \%$ teachers were male and $85 \%$ were under 40 . About half of the respondents were trained in sport science and had 1-2 years teaching experience. Over $90 \%$ of teachers perceived they have knowledge to teach and can manage students. However, $80 \%$ felt they need more exposure and training. Male teachers were better than female teachers in managing students and conducting activities/experiments. Experienced teachers were better in conducting activities and experiments. Teachers majoring in sport science were more knowledgeable while PE majors found teaching sport science challenging. Most teachers perceived that teaching facilities, financial allocation and reference resources were inadequate. Majority of the administrators consulted teachers before assigning teaching load but failed to observe teaching. This research provides invaluable feedbacks on the implementation of the programme.
\end{abstract}

Keywords: Sport science, curriculum implementation, teaching ability, programme evaluation

\section{Introduction}

Here introduce the paper, and put a nomenclature if necessary, in a box with the same font size as the rest of the paper. The paragraphs continue from here and are only separated by headings, subheadings, images and formulae. The section headings are arranged by numbers, bold and $10 \mathrm{pt}$. Here follows further instructions for authors.

\footnotetext{
${ }^{a}$ Corresponding author: weeeh@acd.tarc.edu.my
} 
This study examined the implementation of a new sport science curriculum in secondary schools in Malaysia. This study is significant for the Ministry of Education Malaysia, as previous researchers, [4, 6, 12 and 22] have reported problems and difficulties in implementing new curriculum which include resource problem, untrained staff, students' motivation, preparing teachers, leadership and management, and lack of teachers' observation and guidance. This evaluation provides feedback on the effectiveness of the curricular implementation and the extent to which programme objectives and outcomes were met (impact evaluation). Thus the objective was to evaluate the sport science programme implementation in terms of 'teaching ability', 'administration of sport science programme', 'sport science teaching duty allocation' and 'non-human factors'.

\section{Method}

\subsection{The participants}

The target population of this study includes sport science teachers from secondary school that offer sport science as a subject in the school curriculum. They were either qualified in sports science or physical education as stipulated by the Ministry of Education's ruling. The sample size was based on the list provided by the Curriculum Development Center of Malaysia. Participants comprise a purposive sample of 135 schools and 94 teachers in Malaysia.

\subsection{The Instrument}

The instrument consist of three sections. Section A: Personal Data. The items relate to age of respondent, sex, marital status, race, academic qualification, and professional qualification, field of specialization and working experience and teaching work load. Section B: Teaching and School related information. This section contains items related to teaching and school. The items focus on the number of Sports Science classes, perception on the ability to teach Sports Science. Section C: Information on implementation of Sports Science programme this section consists of 6 items related to the non-human factor of Sports Science programme implementation and 5 items focuses on the distribution of Sports Science classes. Seven items relating to the administration of Sports Science in school.

The perceptions of teachers were based on 'teaching ability' (5 items), 'administration of sport science programme' (7 items), 'sport science teaching duty allocation' (5 items) and 'non-human factors' ( 6 items). The alpha value for the 23 perception items was 0.787 .

\subsection{Data collection and analysis}

The collection of data was through mailing of questionnaires to the listed secondary schools. Items on the 'administration of sport science programme' and 'sport science teaching duty allocation' were weighed on a priori weight method from Almost Always (5) to Almost Never (1). The Likert Scales used were as follows: Almost Always (5), Frequently (4), Occasionally (3), Rarely (2), Almost Never (1).

Items of 'teaching ability' and 'non-human factors' were weighed on a priori weight method from Strongly Agree (5) to Strongly Disagree (1). The Likert scales used were as follows: Strongly Agree (5), Agree (4), Undecided (3), Disagree (2), Strongly Disagree (1).

Two types of statistical techniques were used to analyses the data, namely, descriptive and inferential statistics. Descriptive statistics such as means, standard deviations, 
minimum and maximum were used to report the data from the questionnaire. Inferential statistics such as t-test, and analysis of variance (ANOVA) were used. T-tests were computed to determine whether differences existed in the perception mean scores for each sub-category or items. Several one-way ANOVA were computed to determine whether differences existed between the perception mean scores for the independent factors of gender, age, and race, field of specialization, working experience, and school background. All t-test and ANOVA in this study were carried out using SPSS for Windows (ver.21). All tests of significance were at the .05 level. For the one-way ANOVA, where F-tests were significant, a post-hoc test using the Tukey-HSD test was employed.

\section{Results and Interpretations}

\subsection{Description of the responding teachers}

The results showed that there were more male $(80.9 \%)$ than female $(19.1 \%)$ respondents. This did not reflect the general notion that the teaching profession is dominated by female teachers. By age, the majority of respondents $(56.4 \%)$ were between 30 - 39 years in age. About $85.1 \%$ of the Sport Science teachers were below 40 which reflected that the Sport Science teachers were young.

In terms of academic qualification, the sample is made-up of $86.2 \%$ of graduates in Sport Science, Physical and Health Education, and Education. With regard to professional qualification, more than half of the respondents $(56.4 \%)$ had undergone degree in education programme while $13.8 \%$ had Diploma in Education. About 30\% (27.7\%) were former teachers who furthered their studies in the relevant bachelor programs in the universities.

One third of the total number of Sports Science teachers had less than 1 year teaching experience as Sports Science teachers, majority (57.4\%) have $1-2$ years teaching experience in teaching Sports Science subject, thus showing that they were new Sport Science teachers. On the contrary only 12.8 per cent of the respondents had 3-4 year experience in teaching Sports Science.

A large number of teachers (54.3\%) were trained in Sports Science and 36.2 per cent were trained in Physical and Health Education. This indicates that there is no shortage of Sports Science teachers because the Physical and Health Education teachers are capable of teaching Sports Science subject.

\subsection{Teaching ability of sport science teachers}

A total of 5 statements listed under teaching ability were given to Sport Science teachers. The respondents had to state whether they "strongly agree", "agree", "undecided", "disagree" or "strongly disagree" with the statements. The details in Table 1 indicate that $96.8 \%$ of the respondents agreed that they can manage their students, $94.6 \%$ of the respondents agreed that they 'had knowledge to teach Sports Science', More importantly $79.7 \%$ of the respondents 'strongly agreed' and 'agreed' that they need to attend Sports Science courses before handling the subject. Similarly $77.7 \%$ of the respondents 'strongly agreed' and 'agreed' that they need exposure through Staff Training Programmes.

\subsection{Sport science teachers' perceptions on the administration of sport science programme}

Table 2 reveals teachers' perceptions on the implementation of Sports Science programme in school. It was found that only 59.3 percent of the administrators 'frequently' and 
'always' assumed that Sports Science is important. This is supported by the fact that only 65.7 percent of the administrators 'frequently' and 'always' had discussions with teachers before assigning them to teach Sports Science. Similarly, it was noted that 79.4 percent of administrators 'never', 'rarely' and 'occasionally' discuss with teachers on factors affecting the teaching and learning of Sports Science. The data in the same table also show that low status was accorded to Sports Science by the administrators as it revealed that 93.4 percent of administrators 'never', 'rarely' and 'occasionally' organise staff development programmes.

On facilities for Sports Science, Table 2 shows that 18.7 percent of administrators 'frequently' and 'always' provide adequate facilities for the teaching of Sports Science.

As for class observation, data in Table 2 show that 71.4 percent of the administrators 'never', 'rarely' and 'occasionally' observe teaching of Sports Science. However, it is heartening to note that 97.8 percent of administrators 'never', 'rarely' and 'occasionally' allow Sports Science class to be used for the teaching of other academic subjects.

Table 1 Extent of agreement on ability to teach sport science subject

\begin{tabular}{llllll}
\hline tatements & \multicolumn{3}{c}{ Extent of agreement (\%) } \\
\cline { 2 - 6 } & $\mathrm{SA}$ & $\mathrm{A}$ & $\mathrm{U}$ & $\mathrm{D}$ & $\mathrm{SD}$ \\
\hline I have knowledge to teach Sports Science & 35.1 & 59.6 & 4.3 & 1.1 & 0 \\
I can manage students in my class & 39.4 & 57.4 & 3.2 & 0 & 0 \\
I can conduct activities/ experiments & 34.0 & 56.4 & 9.6 & 0 & 0 \\
I need to attend Sports Science course before handling & 34.0 & 45.7 & 9.6 & 9.6 & 1.1 \\
Sports Science subject & & & & & \\
I needed exposure on Sports Science through Staff & 26.6 & 51.1 & 10.6 & 9.6 & 2.1 \\
Training Programme & & & & & \\
\hline Notes: SA = Strongly Agree; A A Agree; U Undecided; D D Disagree; SD = Strongly Disagree
\end{tabular}

Table 2 Extent of occurrence in the administration of Sports Science programme as perceived by teachers

\begin{tabular}{|c|c|c|c|c|c|}
\hline \multirow[t]{2}{*}{ Statement } & \multicolumn{5}{|c|}{ Extent of Occurrence in Percentage } \\
\hline & $\mathrm{N}$ & RLY & OLY & FLY & $\mathrm{AL}$ \\
\hline $\begin{array}{l}\text { Administrators have discussion before } \\
\text { assigning Sports Science teachers }\end{array}$ & 9.9 & 8.8 & 15.4 & 35.2 & 30.7 \\
\hline $\begin{array}{l}\text { Administrators assume that Sports Science is } \\
\text { important }\end{array}$ & 6.6 & 7.7 & 26.4 & 32.9 & 26.4 \\
\hline $\begin{array}{l}\text { Administrators allow Sports Science class to } \\
\text { be used for other subjects }\end{array}$ & 82.3 & 12.2 & 3.3 & 2.2 & 0.0 \\
\hline Administrators observe teaching & 9.9 & 12.1 & 49.4 & 23.1 & 5.5 \\
\hline $\begin{array}{l}\text { Administrators provide adequate facilities for } \\
\text { Sports Science }\end{array}$ & 14.3 & 30.7 & 36.3 & 16.5 & 2.2 \\
\hline $\begin{array}{l}\text { Administrators organise Staff Development } \\
\text { Training Course for Sports Science }\end{array}$ & 49.4 & 29.7 & 14.3 & 5.5 & 1.1 \\
\hline $\begin{array}{l}\text { Administrators discuss with teachers } \\
\text { concerning factors affecting the teaching and } \\
\text { learning of Sports Science }\end{array}$ & 26.1 & 20.7 & 32.6 & 16.3 & 4.3 \\
\hline
\end{tabular}

Notes: $\quad N=$ Never; $\quad R L Y=$ Rarely; OLY=Occasionally; FLY = Frequently $A L=$ Always 


\subsection{Sport science teachers' perception on teaching class allocation}

Table 3 Sports Science teachers' perceptions on class allocation of the Sports Science programme

\begin{tabular}{llllll}
\hline Statement & \multicolumn{3}{l}{ Extent of Occurrence in Percentage } & \\
\cline { 2 - 6 } & $\mathrm{N}$ & RLY & OLY & FLY & AL \\
\hline $\begin{array}{l}\text { It was determined after a discussion with the } \\
\text { administrators }\end{array}$ & 12.1 & 8.8 & 19.8 & 29.7 & 29.6 \\
$\begin{array}{l}\text { It was assigned to me based on my interest } \\
\text { It was assigned to me based on my Physical }\end{array}$ & 24.2 & 7.7 & 22.0 & 25.3 & 20.8 \\
$\begin{array}{l}\text { Education/Sport Science qualification } \\
\text { It was assigned to me without my knowledge }\end{array}$ & 67.0 & 14.3 & 11.0 & 3.3 & 51.1 \\
$\begin{array}{l}\text { It was assigned as a filler to make up the total } \\
\text { number of periods taught }\end{array}$ & 75.8 & 16.5 & 1.1 & 4.4 & 2.4 \\
\hline
\end{tabular}

Notes: $\quad N=$ Never; $\quad R L Y=$ Rarely; $O L Y=$ Occasionally; FLY = Frequently; $\quad A L=$ Always

Data in Table 3 shows that 60 percent of the administrators 'frequently' and 'always' discuss with the teachers before assigning teaching period to them. However only 45 percent of the administrators 'frequently' and 'always' assign the classes based on teachers' interest. Fortunately, 85 percent of administrators assign their teachers according to their Physical Education/Sports science qualifications. In addition data also show that 81 percent of the teachers have knowledge about their class assignment. 92 percent of the administrators did not assigned Sports Science period to teachers to make up the total number of teaching period.

\subsection{Sport science teachers' perception on non-human factors}

Table 4 revealed that facilities are inadequate $(63.9 \%$ 'disagreed' and 'strongly disagreed' that facilities are adequate), financial allocation is inadequate $(58.5 \%$ 'disagreed' and 'strongly disagreed' that financial allocation is adequate), teaching aids are scarce $(79.8 \%$ 'disagreed' and 'strongly disagreed' that teaching aids are adequate), reference books are inadequate (79.8\% 'disagreed' and 'strongly disagreed' that reference books are adequate), reference books in the national language are inadequate $(71.2 \%$ 'disagreed' and 'strongly disagreed' that reference books in national language are adequate).

Table 4 Extent of Agreement on Statements of Non-human Factors as Perceived by Sports Science teachers

\begin{tabular}{|c|c|c|c|c|c|}
\hline \multirow{2}{*}{ Statements } & \multicolumn{5}{|c|}{ Extent of Agreement in Percentage } \\
\hline & SA & A & $\mathrm{U}$ & $\mathrm{D}$ & SD \\
\hline The class facilities for Sport Science are adequate & 4.3 & 11.7 & 20.2 & 42.6 & 21.3 \\
\hline Financial allocation for Sport Science is adequate & 2.1 & 13.8 & 25.5 & 34.0 & 24.5 \\
\hline Sport Science teaching aids are adequate & 1.1 & 4.3 & 14.9 & 54.3 & 25.5 \\
\hline Sport Science reference books are adequate & 3.2 & 5.3 & 11.7 & 47.9 & 31.9 \\
\hline Sport Science reference books are suitable & 5.3 & 25.5 & 33.0 & 24.5 & 11.7 \\
\hline $\begin{array}{l}\text { There are adequate Sport Science reference books in national } \\
\text { language }\end{array}$ & 1.1 & 8.5 & 19.1 & 37.2 & 34.0 \\
\hline
\end{tabular}




\section{Discussions}

The purpose of this investigation was to evaluate the implementation of sport science programme in Malaysian secondary schools according to sport science teachers' perceptions on teaching ability, administration of sport science programme, class allocation and non-human factors. The discussions are according to the four above-mentioned subareas.

\subsection{Sport science teachers' teaching ability}

The results in section 3.2 indicate that the sport science teachers had knowledge, can manage students and can conduct activity/experiment. Despite that they felt that they need more exposure and require staff development programme (SDP).

Teachers are the most powerful factor in the whole educational process, [7]. The way teacher works professionally makes a difference in the way students learn as improved teaching requires improved teachers. The importance of teacher's ability is emphasized by Seyfarth [24] in his book 'Personnel Management for Effective Schools' that capable teachers are essential in achieving quality education and that such teachers will always be in short supply. This is supported by Grineski [8] that successful education programme start with an effective teacher. In addition, Capel, Leask and Turner [1] in their study revealed that effective teaching depends on professional knowledge, subject knowledge and professional judgement. Professional knowledge is about teaching and learning. Subject knowledge comes through academic qualification and from continuing professional development. Professional judgement refers to routine skills and strategies which support efficient class room management. They added that a widening knowledge base is imperative to bring a deeper understanding of the subject than is required by the syllabus. Wider knowledge help teachers develop differentiated tasks much more easily and it gives teachers the confidence in answering questions posed by students.

Seyfarth [24] in agreement with the above notion stressed that teachers' knowledge of the subjects they teach and the appropriate methods used are important to ensure students' learning. The importance of subject matter is also agreed upon by [20]. Reynolds [21] emphasised that teachers with an inadequate knowledge base place their students at risk of educational failure. He believes that teachers must know their students in a way that would allow them to tailor the subject matter, curricular material and instructional activities to the student.

On the needs of sport science teachers to attend staff training programme despite having knowledge, it may be explained by examining teachers' self-efficacy. The results on teachers demographic showed that $86 \%$ of sport sciences teachers had 2 years and below experience. According to Huberman's [10] professional life cycle of teachers, teachers undergo a process of survival and discovery in the early career years (before 4 years), during which the teachers are gulf between professional ideals and daily classroom life, and self-doubts and initial enthusiasm. The self-doubts has undoubtedly influenced the teachers in this current study to attend courses and seeking more exposure even though they perceived that they have knowledge to teach and carry out experiment in their sport science classes. The result is contrary to Wee's [28] findings on PE teachers which revealed that despite being rated as weak, only $22 \%$ PE teachers studied were interested to attend courses. 


\subsection{Sport science teachers' perceptions on the administration of sport science programme}

The results in section 3.3 revealed that administrators did not organize staff development programme (SDP), did not had discussion on factors affecting teaching with teachers and did not observe teachers' teaching.

SDP is important to provide not only content knowledge, adequate materials and essential resources but to provide time for teachers to integrate the new skills in their curriculum.. Guskey [9] believed that SDP provide assistance to teachers to discover or rediscover their untapped potentials. This is support by Pate and Thompson [19] that content-specific professional development (curricular and instructional alternatives, assessments, learning styles, and adolescent development) allows teachers to make their classroom a more constructive learning environment. Further, Pate and Thompson [19] emphasized that SDP invites collaborative discussion among teachers. By collaborating, Corcoran [3] and Diaz-Maggioli [5] suggested that teachers would be able to discover instructional strategies, test ideas together, critically examine new standards and revise curriculum. The collaboration would transformed their teaching. Similarly Leithwood et al. [11] discovered three basic leadership practices for school success were setting direction, developing people, and redesigning the organization.

In Malaysia, the Ministry of Education requirements [16] specified that school principals must plan, administer and evaluate school SDP. School heads must identify the strengths and weaknesses of the teaching staff and plan SDP based on the identified needs. In addition, they must also monitor and take appropriate corrective action to change the SDP to ensure its effectiveness. The status of SDP was reported by Sebastian [23] in his study of PE programme, where $30.8 \%$ of schools never organized SDP, $62.9 \%$ organized 13 times annually. MOE [18] reported 29.4\% secondary school organized SDP. Similarly, Wee [28] reported that only $14 \%$ of the principals in 290 secondary schools organized inhouse SDP. In the earlier study of 120 secondary schools, Federal Inspectorate of Schools (1988) found that a majority of the principals (75.9\%) did not focus on planning and administration of the SDP in their respective schools. The findings revealed that 29 principals $(24.1 \%)$ carried out their duty well and were graded as very good and good by the Federal Inspectorate of Schools.

The high incidence regarding the lack of observation and supervision of PE lessons by Principals was reported by Malaysian researchers [25]. Wee [28] reported that only about $50.6 \%$ of principals 'frequently' and always' did so, $6 \%$ of the principals delegated the observation responsibilities to their assistants. Previously the lack of supervision in PE was reported in the Secondary School Inspection Report (SSIR) (2007); only 18.5\% (8 of 46 schools) carried out the mandatory s supervision at school level.

\subsection{Sport science teachers' perception on teaching class allocation}

Results in Section 3.4 showed that only 60 percent of the administrators discussed with the teachers before assigning teaching period to them and only 45 percent of the administrators assigned the classes based on teachers' interest. Research in the area of sport science is scares as such we will discuss this issue in the light of research evidence from PE.

Wee [28] reported in the case of PE teachers that school administrators did not practice consensus in allocating teaching periods to teachers. In addition Wee also reported that almost $80 \%$ of the administrators did not take teachers' interest when assigning to teach. Wee [28] revealed that majority of the PE teachers did not choose to teach PE. There was no discussion between the administrators and themselves and a large majority of them 
agreed that they accepted PE classes given to them involuntarily. This also indicated that administrators did not take into consideration teachers' interest.

\subsection{Sport science teachers' perception on non-human factors}

Results in section 3.5 revealed that facilities, financial allocation, teaching aids, reference books including reference books in the national language were inadequate.

In examining Malaysian PE programme, Wee [28] and Chong and Salamuddin [2] found that facilities and equipment were inadequate. Wee also reported that financial allocation and reference books for PE were inadequate. Similarly McNeill et al. [14] revealed in Singapore, $42 \%$ of PE teachers felt that their school facilities were inadequate.

On the inadequacy of financial support, the Malaysian Federal Inspectorate of Schools (1994/1995) reported that financial allocations in schools were not properly planned. The survey which involved 118 schools in 7 states in Peninsular Malaysia showed that even though the head teachers were told about the allocations, they failed to act accordingly. Plans to acquire equipment for long term and short term use were not discussed thoroughly in the committee meetings. In fact, previously in 1990, the Federal Inspectorate of Schools in their study of 11 schools reported that schools lacked reference materials such as syllabuses and guide books.

\section{Conclusion}

This study evaluate the implementation of sport science programme in Malaysian secondary schools according to sport science teachers' perceptions on teaching ability, administration of sport science programme, class allocation and non-human factors. About $85 \%$ of the Sport Science teachers were young (below 40). Majority of teachers had teaching experience less than 2 years. Most Sports Science teachers perceived that they have knowledge to teach Sports Science subject in school and they can manage their students. The results revealed that administrators did not organize staff development programme (SDP), did not had discussion on factors affecting teaching with teachers and did not observe teachers' teaching. In addition, research data also showed that 60 percent of the administrators discussed with the teachers before assigning teaching period to them, however only 45 percent of the administrators assigned the classes based on teachers' interest. Research findings also revealed that facilities, financial allocation, teaching aids, reference books including reference books in the national language were inadequate. In short, despite the variations in the findings, Sports Science programme was implemented with some success.

\section{References}

1. Capel, S., Leask, M. \& Turner, T., Learning to teach in the secondary school: a companion to school experience. London: Routledge, (1995).

2. Chong, A. L. \& Norlena, S., The implementation of physical education in secondary school: A preliminary study. Proceedings of the International Seminar Comparative Studies In Educational System Between Indonesia \& Malaysia, 15-16 June. University of Education Indonesia, Bandung, pp.955-971, (2010).

3. Corcoran, T., Helping teachers teach well: Transforming professional development. Consortium for Policy Research in Education Policy Briefs. Retrieved from http://www.ed.gov/pubs/CPRE/t61/index.html, (1995, June). 
4. Croll, P. \& Moses, D., Perspectives on the National Curriculum in Primary and Secondary Schools. Educational Studies, 16 (2), 187-198, (1990).

5. Diaz-Maggioli, G. (2004). Teacher-centered professional development. Alexandria, VA: Association for Supervision and Curriculum Department.

6. Fetterman, D.M., Deitz, J. \& Gesundheit, N., Empowerment evaluation: A collaborative approach to evaluating and transforming a medical school curriculum. Academic Medicine, 85(5), 813-820, (2010).

7. Frymier, J.R. \& Hawn, H.C., Curriculum improvement for better schools. Worthington, Ohio: Charles A. Jones, (1970).

8. Grineski, S., The image and future of physical education: Cultural inertia. Proceedings. Conference on the Future of Physical Education. Brockport: State University of New York, (1994, October).

9. Guskey, T. R., Professional development in education: In search of an optimum mix. In T. Guskey \& M. Huberman (Eds.), Professional Development in Education: New Paradigms and Practices (pp. 114-131). New York, NY:Teachers College Press, Columbia University, (1995).

10. Huberman, M., The professional life cycle of teachers. Teachers College Record, 91, 31-57, (1989).

11. Leithwood, K., Seashore-Louis, K., Anderson, S., \& Wahlstrom, K., Review of research: How leadership influences student learning. New York: Wallace Foundation, (2004).

12. Lynch, P.D. \& Saifelislam, O., The Implementation of the New Educational Policy in the Sudan, 1970-85: promise and reality. Educational Review, 41(3), 257-261, (1989).

13. Robinson, M.H., Middle school teachers' perceptions of professional development experiences. Doctor of Education dissertation, Western Carolina University, USA, (2011).

14. McNeill, M., Lim, B.S.C., Wang, C.K.J., Tan, W.K.C., \& MacPhail, A., Moving towards quality physical education: Physical education provision in Singapore. European physical education review, 15, 201-223, (2009).

15. Ministry of Education, Malaysia [MOEM], Report on the teaching of physical education in secondary school (In National Language of Malaysia). Kuala Lumpur: Federal Inspectorate of Schools, (1988).

16. Ministry of Education Malaysia [MOEM], Letter of professional service. No.2/1998 (In National Language of Malaysia). Kuala Lumpur: Author, (1998).

17. Ministry of Education Malaysia [MOEM], Report on the Teaching of Physical Education in Secondary School. (In National Language of Malaysia). Kuala Lumpur: Federal Inspectorate of Schools [FIS], (1994/95).

18. Ministry of Education Malaysia [MOEM], Secondary School Inspectorate Report. (In National Language of Malaysia). Kuala Lumpur: FIS, (2007).

19. Pate, E., \& Thompson, K., Effective professional development: What is it? In G. Andrews, \& V. Anfara, Jr. (Eds.), Leaders for a Movement (pp. 123-143). Westerville, $\mathrm{OH}$ : Information Age, (2003).

20. Porter, A.C. \& Brophy, J., Synthesis of research on good teaching: insights from the work of the institute for research on teaching. Educational Leadership, 45(8), 74-85, (1988).

21. Reynolds, D., 'The effective school', Managing Schools Today, 1(7), 16-18, (1992).

22. Schlairet, M.C., Simulation in an undergraduate nursing curriculum: implementation and impact evaluation. The Journal of Nursing Education, 50(10), 561-568, (2011).

23. Sebastian, B.A.S., Comparative study of the implementation of Physical Education Programme in Bintulu and Shah Alam secondary schools. Undergraduate Project, Uiniversiti of Teknologi MARA, (2006). 
24. Seyfarth, J.T., Personnel management for effective schools. Massachusetts: Allyn \& Bacon, (1991).

25. Tan, S. E., \& Lee, F. K., Reviving physical education in schools: A small dosage of management and commitment from the educational leaders. The Journal of Administrative Science, 14(1), 45-52, (2004).

26. Thompson, A., Caring in Context: Four Feminist Theories on Gender and Education. Curriculum Inquiry, 33(1), 9-65, (2003).

27. Thomson, R., Managing People. Oxford: Butterworth-Heinemann, (1993).

28. Wee, E.H., Contemporary issues in the teaching of PE in Malaysia. J Physical Activity, Sport \& Exercise, 1(1), 17-20, (2013).

29. Wee, E.H., 'Perceptions of non-PE major teachers on the implementation of Malaysian secondary school PE program'. Proceeding of the 7th International Scientific Conference on Kinesiology (22-25 May 2014) in Opatija, Croatia, (2014). 